\title{
Effects of CYP2D6 and UGT2B7 polymorphisms on pharmacokinetics of tamoxifen in Thai breast cancer patients
}

\author{
N Areepium' \\ D Panomvana' \\ P Rungwanonchai' \\ S Sathaporn ${ }^{2}$ \\ N Voravud ${ }^{3}$ \\ 'Department of Pharmacy \\ Practice, Faculty of Pharmaceutical \\ Sciences, Chulalongkorn University, \\ Bangkok, ${ }^{2}$ Department of Surgery, \\ Phramongkutklao Hospital, Bangkok, \\ ${ }^{3}$ Department of Medicine, Faculty of \\ Medicine, Chulalongkorn University, \\ Bangkok, Thailand
}

This article was published in the following Dove Press journal:

Breast Cancer:Targets and Therapy

2I August 2013

Number of times this article has been viewed

Purpose: The objective of this study was to evaluate the impact of CYP2D6 and UGT2B7 polymorphisms on tamoxifen (TAM) pharmacokinetics in Thai breast cancer patients.

Methods: Thai female breast cancer patients treated with TAM were included in the study. Patients were genotyped for CYP2D6 and UGT2B7 polymorphism, and plasma levels of TAM and its potent active metabolite endoxifen (END), at steady state, were identified.

Results: Fifty-nine female breast cancer patients were included in the study. The average age was $50 \pm 9.3$ years old; $76 \%$ were premenopausal and $85 \%$ had estrogen receptor-positive breast cancer. The allele frequencies of $C Y P 2 D 6^{*} 10$ and $U G T 2 B 7 * 2$ were $53 \%$ and $28 \%$, respectively. Patients with $C Y P 2 D 6 * 10 / * 10$ had lower END concentrations compared with $C Y P 2 D 26 * 1 / * 10$ and $C Y P 2 D 6^{*} 1 / * 1(9.62 \mathrm{ng} / \mathrm{mL}$ versus $15.67 \mathrm{ng} / \mathrm{mL}$ and $21.55 \mathrm{ng} / \mathrm{mL}$, respectively, $P=0.045)$. Polymorphisms of $U G T 2 B 7$ alone did not have any impact on TAM metabolism. However, among 20 patients with $C Y P 2 D 6 * 10 / * 10$, one with $U G T 2 B 7 * 2 / * 2$ had higher END concentrations compared against patients with $U G T 2 B 7^{*} 1 / * 1$ and $U G T 2 B 7^{*} 1 / * 2(31.36 \mathrm{ng} / \mathrm{mL}$ versus $7.86 \mathrm{ng} / \mathrm{mL}$, respectively, $P=0.023)$.

Conclusion: Results from this study confirmed the impacts of $C Y P 2 D 6$ polymorphisms on the pharmacokinetics of TAM, while $U G T 2 B 7$ polymorphisms tended to have impact on TAM metabolism in patients with homozygous CYP2D $6 * 10$.

Keywords: tamoxifen, pharmacogenomics, CYP2D6, UGT2B7, breast cancer

\section{Introduction}

Breast cancer $(\mathrm{BC})$ is the most common cancer among females and the leading cause of cancer-related death. ${ }^{1}$ About two-thirds of patients with $\mathrm{BC}$ are classified as estrogen receptor (ER) positive, with tumor growth stimulated by estrogen. Adjuvant hormonal therapy reduces almost half of $\mathrm{BC}$ recurrence. In postmenopausal BC patients, aromatase inhibitors (AIs) are the preferred option, while in pre- and peri-menopausal patients, whose ovaries still retain the function of estrogen production, tamoxifen (TAM) is almost the only choice. ${ }^{2}$

TAM is a pro-drug that is metabolized to produce active metabolites, of which 4-hydroxy-N-desmethyltamoxifen, or endoxifen (END), is the most potent. The biotransformation of TAM to END is processed through cytochrome P450 (CYP450) enzymes. CYP2D6 is the most important enzyme for the hydroxylation reactions, while UDP-glucuronosyltransferases (UGTs) are important for increasing the solubility and facilitating the excretion of TAM and its metabolites. ${ }^{2-4}$

There is high inter-individual variation among patients receiving TAM treatment, with recurrence of $\mathrm{BC}$ after adjuvant hormonal treatment at $30 \%-50 \%$.

Correspondence: Duangchit Panomvana Department of Pharmacy Practice, Faculty of Pharmaceutical Sciences, Chulalongkorn University, Bangkok 10330, Thailand

Tel +6622188405

Fax +6622188403

Email duangchit.p@chula.ac.th 
Multiple factors contribute to the failure of TAM treatment; one of the most important factors is polymorphism in the drug-metabolizing enzymes responsible for TAM metabolism. The CYP2D6 gene is a highly polymorphic gene. More than 60 functional variants currently identified have resulted in abolished, decreased, normal, and ultrarapid enzyme activities. CYP $2 D 6 * 4$ and $* 5$ are the most important null alleles, while $C Y P 2 D 6 * 10, * 17$ and $* 41$ are the most common for severely reduced enzyme activity. ${ }^{5-10}$ There are differences in the prevalence of variant alleles among ethnic groups. Caucasians are likely to contain more non-functional CYP2D6*4 alleles ( $12 \%-21 \%$ versus $<5 \%$ in Asians), while prevalence of reduced function $C Y P 2 D 6 * 10$ alleles is much higher among Asians (approximately 50\%). ${ }^{8,10-14}$ In Thais, prevalence of CYP2D6 poor metabolizers was about $1 \%$, while the allele frequency of $C Y P 2 D 6 * 10$ was comparable to other Asian populations, such as Japanese, Korean, and Chinese. ${ }^{10-14}$

Several studies have reported an association between the CYP2D6 genotypes and clinical outcomes in women treated with adjuvant TAM. Evidence from two studies suggested that women with reduced function CYP2D6 who were treated with TAM had a significantly shorter time for recurrence and recurrence-free survival (but not overall survival). ${ }^{15-17}$ Borges et al reported that patients with heterozygous reduced function (eg, $C Y P 2 D 6^{*} 10$ ) and null function (eg, $C Y P 2 D 6 * 4$ ) alleles had lower END concentrations. ${ }^{18}$ This indicated the importance of comprehensive $C Y P 2 D 6$ genotyping in variability of END plasma concentrations.

TAM and its metabolites, including END, are eliminated by glucuronidation. In vitro studies have shown that UGT2B7 is the major hepatic enzyme involved in the O-glucuronidation of the trans isomers of 4-OH-TAM and END. ${ }^{19}$ From an in vitro study, the $U G T 2 B 7^{268 T y r}(* 2)$ variant exhibited a significant 2 - and 5-fold decrease in activity against the trans isomers of 4-OH-TAM and END, respectively. These results suggested that functional polymorphisms in TAM-metabolizing UGTs, including UGT2B7 and, potentially, UGT1A8, may be important in inter-individual variability in TAM metabolisms.

Ethnic differences have also been found in polymorphisms of $U G T 2 B 7 C 802 T$ (His $\left.{ }^{2687 y r}\right) .{ }^{20}$ Results from a study of 91 Australians demonstrated a $25 \%$ proportion of $* 2 / * 2$ genotypes, whereas a Japanese study revealed only $5 \%$ of $U G T 2 B 7 * 2 / * 2 .{ }^{21}$ Among Thais, the most frequent variant was CYP $2 D 6 * 10$ (approximately 60-70\%), which did not differ from other reports on Asian populations. ${ }^{22-24}$ However, the prevalence of $U G T 2 B 7 * 2$ in Thais was not known. Moreover, there has been no study on the impact of $U G T 2 B 7$ polymorphisms on TAM metabolism among Thai BC patients. Our study is the first investigation that intends to evaluate the effects of different polymorphisms of CYP2D6 and UGT2B7 on the pharmacokinetics of TAM; the study is conducted in Thai BC patients.

\section{Patients and methods}

This observational study was conducted from February 2011-January 2012 at the Outpatient Department at Pramongkutkloa Hospital. The study protocol was approved by the Institutional Review Board of the Royal Thai Army Medical Department, and informed consent was obtained from each participant. We hypothesized that polymorphisms of both $C Y P 2 D 6$ and $U G T 2 B 7$ genes would impact the pharmacokinetics of TAM. Therefore, to validate such a hypothesis, plasma concentrations of TAM and END among patients with different genotypes needed to be obtained for this study.

\section{Patients}

Patients who were prescribed TAM as hormonal therapy for BC, and who returned for follow-up at the Outpatient Department at Pramongkutklao Hospital, were approached by investigators to participate in this study. Patients were interviewed by investigators for their demographic details as well as TAM administration, adherence to the TAM treatment regimen, and experience of TAM adverse effects. Other treatments for their underlying diseases, as well as other concomitant complementary and alternative medicines used with TAM, were also recorded. The medical records from each patient were reviewed extensively by the research team, for recording the relevant clinical data.

$\mathrm{BC}$ patients were eligible for the study if they met the following criteria: (1) currently on TAM $20 \mathrm{mg}$ once daily for at least six weeks; (2) age $\geq 20$ years old; (3) normal liver function (aspartate aminotransferase and alanine aminotransferase $\leq 2 \times \mathrm{UNL}$ ); (4) normal renal function (serum creatinine $<1.2 \mathrm{mg} / \mathrm{dL}$ ); and (5) agreed to participate in the study by signing the consent form. Patients who used concomitant drugs that affect (inhibit or induce) CYP2D6, and those who did not comply with the time schedule of TAM administration, were excluded from the study.

\section{Blood sampling and analysis of TAM and END}

At the Outpatient Department, patients' blood samples were collected using EDTA tubes. DNA was afterwards collected 
from a Buffy coated layer. All samples were stored at $-20^{\circ} \mathrm{C}$ until analysis. Plasma concentrations of TAM and END were determined by reverse-phase high-pressure liquid chromatography (HPLC), using a fluorescence detector with minor modifications from Zhu's group. ${ }^{25} \mathrm{In}$ brief, $1 \mathrm{~mL}$ of plasma was added to mexilitine as an internal standard, then $1.5 \mathrm{~mL}$ of acetonitrile was used for protein precipitation. A quantity of $1 \mathrm{~mL}$ of supernatant was transferred to the clear ampoule and left in an ultraviolet lamp hood at a wavelength of $375 \mathrm{~nm}$ for 20 minutes, and then 20 microliters of sample were injected into the HPLC column. HPLC was accomplished by using an Agilent 1200 series liquid chromatography system (Agilent Technologies, Santa Clara, CA, USA) with a binary pump, online degasser, autosampler, column heater, and fluorescence detector. An Agilent Zorbax Extend-C18 chromatography column $(150 \times 4.6 \mathrm{~mm}, 5$ microns $)$, in HPLC condition, consisted of $1 \%$ triethanolamine (aqueous solution $\mathrm{pH}: 11$; methanol: $18: 82 \mathrm{v} / \mathrm{v}$ ). The system was run at a flow rate of $1.1 \mathrm{~mL} / \mathrm{min}$ with the column temperature controlled at $35^{\circ} \mathrm{C}$. The fluorescence detector was set at an excitation wavelength of $260 \mathrm{~nm}$ and emission wavelength of $375 \mathrm{~nm}$. The retention times for TAM, END and internal standard were 16, 3.8 and 2.5 minutes, respectively.

\section{Genotyping of CYP2D6 and UGT2B7}

QIAamp DNA Mini Kits (Qiagen, Bangkok, Thailand) were used to extract genomic DNA from the leukocyte portion of whole blood. DNA samples were genotyped for variant alleles of CYP2D6*10 $(100 \mathrm{C}>\mathrm{T}$; rs 1065852) and $U G T 2 B 7^{*} 2(802 C>\mathrm{T}$; rs7439366). The reaction mixtures contained TaqMan ${ }^{\circledR}$ Drug Metabolism Genotyping Assay Mix (Invitrogen ${ }^{\mathrm{TM}}$, Carlsbad, CA, USA), TaqMan ${ }^{\circledR}$ Universal PCR Master Mix, No AmpErase ${ }^{\circledR}$ UNG, DNaseFree Water Assays, and Master Mix for allele determination. Real-time polymerase chain reaction processes were done using a StepOnePlus ${ }^{\mathrm{TM}}$ Real-time PCR system (Applied Biosystems $^{\circledR}$, Foster City, CA, USA).

\section{Statistical analyses}

All data analyses were performed using SPSS v 17.0 statistical software for Windows (IBM Corporation, Armonk, NY, USA). Data were analyzed using descriptive statistics and inferential statistics. The independent $t$-test and ANOVA (analysis of variance) were used for data with normal distribution, while the Mann-Whitney $U$ test and/or Kruskal-Wallis test were used for comparison of END and TAM plasma concentrations among the different genotypes, in case data were not in normal distribution. A two-sided
Table I Patient characteristics

\begin{tabular}{ll}
\hline Patient characteristic & Mean \pm SD (\% patients) \\
\hline Age (years) & $50 \pm 9.3$ \\
Body mass index & $22.8 \pm 3.8 \mathrm{~kg} / \mathrm{m}^{2}$ \\
Estrogen receptor status & $51(86.4)$ \\
Positive & $4(6.8)$ \\
Negative & $4(6.8)$ \\
Unknown & \\
Progesterone receptor status & $50(84.7)$ \\
Positive & $7(11.9)$ \\
Negative & $2(3.4)$ \\
Unknown & \\
HER-2 & $5(8.5)$ \\
Positive & $45(76.3)$ \\
Negative & $5(8.5)$ \\
Unknown & \\
Menopausal status & $45(76.3)$ \\
Pre/peri-menopause & $14(23.7)$ \\
Post-menopause & \\
TNM stage & $24(40.6)$ \\
TI & $18(30.5)$ \\
T2 & $4(6.8)$ \\
T3 & $3(5.1)$ \\
T4 & $33(55.9)$ \\
N0 & $7(11.9)$ \\
N1 & $9(15.3)$ \\
N2 & $56(94.9)$ \\
M0 & $4(6.8)$ \\
MI & $10(16.9)$ \\
Unknown &
\end{tabular}

Abbreviations: SD, standard deviation; HER-2, Human Epidermal Growth Factor Receptor 2

$P$-value of less than 0.05 was considered to be statistically significant for all analyses.

\section{Results}

Fifty nine BC patients were included in the study. Their average age was $50 \pm 9.3$ years old, and their average weight, height, body mass index, and body surface area were, $58.3 \pm 9.8 \mathrm{~kg}, 156.6 \pm 5.5 \mathrm{~cm}, 22.8 \pm 3.8 \mathrm{~kg} / \mathrm{m}^{2}$, and $1.56 \mathrm{~m}^{2}$, respectively. Most patients were in their forties ( 24 cases, $40.7 \%$ ). The majority were early stage BC cases (70\% of cases had T1 and T2 tumor stage, and 50\% did not have node involvement). Most of the patients (86\%) were ER-positive BC. The duration of TAM treatment was in the range of 1.5-79 months (median: 26 months). The patients' characteristics are given in Table 1.

Table 2 Genotype frequency of CYP2D6 and UGT2B7

\begin{tabular}{llllll}
\hline \multicolumn{5}{c}{$\begin{array}{l}\text { Allele frequency } \\
(\%)\end{array}$} & $\begin{array}{l}\text { Genotype } \\
\mathbf{n}(\%)\end{array}$ \\
\hline CYP2D6 & $* 1$ & $* 10$ & $* I /{ }^{\prime}$ & $* I / * 10$ & $* 10 / * 10$ \\
& 47 & 53 & $16(27.1)$ & $23(39)$ & $20(33.9)$ \\
UGT2B7 & $* 1$ & $* 2$ & $* I / * 1$ & $* I / * 2$ & $* 2 / * 2$ \\
& 72 & 28 & $31(52.5)$ & $23(39)$ & $5(8.5)$ \\
\hline
\end{tabular}


Table 3 TAM and END concentrations in different CYP2D6 genotypes

\begin{tabular}{lllll}
\hline $\begin{array}{l}\text { Plasma concentration } \\
(\mathbf{n g} / \mathbf{m L})\end{array}$ & $\begin{array}{l}\text { CYP2D6*II*I } \\
(\mathbf{n}=16)\end{array}$ & $\begin{array}{l}\text { CYP2D6*I/*I0 } \\
(\mathbf{n}=\mathbf{2 3})\end{array}$ & $\begin{array}{l}\text { CYP2D6*I0/*I0 } \\
(\mathbf{n}=\mathbf{2 0})\end{array}$ \\
\hline TAM $^{\mathrm{a}}$ & $323.6 \pm 79.8$ & $336.3 \pm 151.1$ & $437.3 \pm 161.2$ & $0.027^{*}$ \\
END $^{\mathrm{b}}$ & 21.55 & 15.67 & 9.62 & $0.045^{\#}$ \\
\hline
\end{tabular}

Notes: ${ }^{\mathrm{M}}$ Mean; ${ }^{\mathrm{b}}$ median (END concentrations were reported as median due to the non-normal distribution of data); ${ }^{* P}$-value as ANOVA test; ${ }^{\# P}$-value as Kruskal-Wallis test. Abbreviations: TAM, tamoxifen; END, endoxifen; ANOVA, analysis of variance.

\section{Prevalence of CYP2D6 and UGT2B7 genotypes}

$C Y P 2 D 6^{*} 10$ and $U G T 2 B 7 * 2$ allele frequencies and the distribution of genotypes of both genes are shown in Table 2. The frequencies of both CYP2D10 and UGT2B7 were within the Hardy-Weinberg equilibrium.

\section{Plasma concentrations of TAM and END among different genotypes}

Ranges of TAM and END plasma concentration were $28.12-714.56 \mathrm{ng} / \mathrm{mL}$ and $1.88-66.15 \mathrm{ng} / \mathrm{mL}$, respectively, which indicated a large inter-individual variation of TAM metabolism among Thai BC patients. Polymorphisms of CYP2D6 showed impacts on the pharmacokinetics of TAM, through significant differences in plasma concentrations of TAM and END. Patients with the variant allele CYP2D6*10 had higher TAM and lower END plasma concentrations. Plasma concentrations of TAM and END among different CYP2D6 genotypes are shown in Table 3. Polymorphisms of $U G T 2 B 7$ alone did not show any impact on TAM metabolism. However, the subgroup of homozygous $C Y P 2 D 6^{*} 10$, patients with homozygous $U G T 2 B 7^{*} 2$, tended to have higher END plasma concentrations, as shown in Tables 4 and 5, respectively. The impact of $U G T 2 B 7 * 2$ on END plasma concentrations was regarded as significant when comparing patients with homozygous $U G T 2 B 7 * 2$ and those with at least one full functioning allele of $U G T 2 B 7^{*} 1$, as shown in Table 6.

\section{Discussion}

The findings reported in this study are similar to those of many other studies, ${ }^{27-29,31}$ for the allelic frequency of
CYP2D6 polymorphism *10 (which indicated decreased enzyme activity). Our results were comparable with those from other studies of Thai and Asian populations. We found that most of our patients (33\%) had the homozygous variant CYP $2 D 6^{*} 10 / * 10$, similar to the results of Sirachainan et $\mathrm{al}^{26}$ and Pechatanan et al, ${ }^{23}$ who found the homozygous variant CYP $2 D 6 * 10 / 10$ in $55 \%$ and $42 \%$ of BC patients, respectively. The main objective of these studies was to elucidate on the impacts of CYP2D6 polymorphisms on clinical outcomes. However, none of them reported any impact from CYP2D6 on the plasma concentrations of TAM and END. Our results were similar to Jin et al, ${ }^{27}$ who reported statistically lower concentrations of END in patients with the homozygous variant $(\mathrm{Vt} / \mathrm{Vt})$ CYP2D6*4 $(20.0 \mathrm{nM} / \mathrm{mL})$ as compared to patients with the heterozygous variant $(\mathrm{Wt} / \mathrm{Vt})$ and homozygous wild type (Wt/Wt) (43.1 and $78.0 \mathrm{nM} / \mathrm{mL}$, respectively). Also, the findings are similar to those of Madlensky et al, ${ }^{28}$ who also reported that END concentrations in poor metabolizers were only $5.6 \mathrm{ng} / \mathrm{mL}$, compared to $8.1,15.9$, and $22.8 \mathrm{ng} / \mathrm{mL}$ in intermediate, extensive, and ultra-extensive metabolizers, respectively. The results from TAM dose adjustment, based on patients' genotype by Kiyatoni et al, ${ }^{29}$ additionally demonstrated a similar pattern. Before the dosing adjustment, all patients received TAM $20 \mathrm{mg} /$ day; the END concentration for patients with the CYP2D6 genotype * $1 / * 10$ was $15 \mathrm{ng} / \mathrm{mL}$, compared to $10 \mathrm{ng} / \mathrm{mL}$ in patients with $C Y P 2 D 6^{*} 10 / * 10$ $(P<0.001)$. In our study, we found the highest END plasma concentrations in patients with homozygous CYP2D6*1/*1 $(21.55 \mathrm{ng} / \mathrm{mL})$. Lower END plasma concentrations were found in heterozygous CYP2D6*1/*10 $(15.67 \mathrm{ng} / \mathrm{mL})$, and the lowest concentration in homozygous CYP $2 D 6^{*} 10 /{ }^{*} 10$ $(9.62 \mathrm{ng} / \mathrm{mL})$.

Table 4 TAM and END concentrations in different UGT2B7 genotypes

\begin{tabular}{lllll}
\hline $\begin{array}{l}\text { Plasma concentration } \\
(\mathbf{n g} / \mathbf{m L})\end{array}$ & $\begin{array}{l}\text { UGT2B7*I/*I } \\
(\mathbf{n}=\mathbf{3 I})\end{array}$ & $\begin{array}{l}\text { UGT2B7*I/*2 } \\
(\mathbf{n}=\mathbf{2 3})\end{array}$ & $\begin{array}{l}\text { UGT2B7*2/*2 } \\
(\mathbf{n}=\mathbf{5})\end{array}$ \\
\hline TAM $^{\mathrm{a}}$ & $362.3 \pm 158.8$ & $360.5 \pm 130.0$ & $427.3 \pm 153.3$ & $\mathbf{P}$-value \\
END $^{\mathrm{b}}$ & 14.12 & 15.33 & 28.74 & 0.613 \\
\hline
\end{tabular}

Notes: ${ }^{a}$ Mean; ${ }^{b}$ median (END concentrations were reported as median due to the non-normal distribution of data).

Abbreviations: TAM, tamoxifen; END, endoxifen. 
Table 5 TAM and END concentrations in subgroup of CYP2D6*10/*10 with different UGT2B7 genotypes

\begin{tabular}{lllll}
\hline $\begin{array}{l}\text { Plasma concentration } \\
(\mathbf{n g} / \mathbf{m L})\end{array}$ & $\begin{array}{l}\text { UGT2B7*I/*I } \\
(\mathbf{n}=\mathbf{8})\end{array}$ & $\begin{array}{l}\text { UGT2B7*I/*2 } \\
(\mathbf{n}=\mathbf{9})\end{array}$ & $\begin{array}{l}\text { UGT2B7*2/*2 } \\
(\mathbf{n}=\mathbf{3})\end{array}$ \\
\hline TAM $^{\mathrm{a}}$ & $395.7 \pm 172.8$ & $311.7 \pm 95.7$ & $410.8 \pm 136.1$ & $\mathbf{P}_{\text {-value }}$ \\
END $^{\mathrm{b}}$ & 9.11 & 7.86 & 31.36 & 0.376 \\
\hline
\end{tabular}

Notes: aMean; ${ }^{b}$ median (END concentrations were reported as median due to the non-normal distribution of data); ${ }^{\# P}$-value as Kruskal-Wallis test. Abbreviations: TAM, tamoxifen; END, endoxifen.

For the enzyme UGT, in this study we found the allele frequency of $U G T 2 B 7 * 2$ to be $28 \%$, which is similar to the results from a Japanese study. ${ }^{21}$ UGT enzymes are mainly responsible for TAM and END excretion via glucuronidation. It was hypothesized that UGT polymorphisms should result in differences in TAM and END concentration among patients with different UGT polymorphisms. To date, there have been many studies reporting the impacts of CYP2D6 polymorphisms on the pharmacokinetics of TAM. However, there are few reports that indicate no impact of $U G T 2 B 7$ on the pharmacokinetics of TAM, as well as some reports revealing no relationship between the polymorphism of UGT2B7 and clinical outcomes of TAM-treated patients. ${ }^{30-32}$ To the best of our knowledge, our study is the first to report the impact of $U G T 2 B 7$ polymorphisms on TAM, in terms of differences in TAM and END plasma concentrations. Although we did not confirm the impact of $U G T 2 B 7$ polymorphism in all BC patients, in patients with impaired CYP2D6 function, by containing the homozygous $C Y P 2 D 6 * 10 / 10$ allele, $U G T 2 B 7$ polymorphism was shown to impact the metabolism of TAM and END. The 20 patients with homozygous reduced function $C Y P 2 D 6 * 10$, along with homozygous $U G T 2 B 7^{*} 2$, had higher END plasma concentrations ( $31.36 \mathrm{ng} / \mathrm{mL}$ ), compared against patients with the least full-functioning $U G T 2 B 7^{*} 1$ $(7.86 \mathrm{ng} / \mathrm{mL})$. Even though the number of patients in this subgroup was small, our results indicated a slight trend that the polymorphisms of both genes could explain the differences in TAM metabolism among BC patients. Further studies with a larger number of patients are needed to evaluate the effects

Table 6 END concentrations in subgroup of CYP2D6*10/*10 with homozygous and heterozygous UGT2B7*I versus homozygous UGT2B7*2 genotypes

\begin{tabular}{llll}
\hline $\begin{array}{l}\text { Plasma } \\
\text { concentration } \\
(\mathbf{n g} / \mathrm{mL})\end{array}$ & $\begin{array}{l}\text { UGT2B7*I/*I and } \\
\text { UGT2B7*I/*2 } \\
(\mathbf{n}=I 7)\end{array}$ & $\begin{array}{l}\text { UGT2B7*2/*2 } \\
(\mathbf{n}=\mathbf{3})\end{array}$ & $\begin{array}{l}\text { P-value } \\
\text { TAM }\end{array}$ \\
END $^{\mathrm{b}}$ & $426.8 \pm 164.0$ & $496.8 \pm 159.7$ & 0.504 \\
\hline
\end{tabular}

Notes: aMean; ${ }^{b}$ median (END concentrations were reported as median due to the non-normal distribution of data); $P$-value as Mann-Whitney $U$ test.

Abbreviations: TAM, tamoxifen; END, endoxifen. of $U G T 2 B 7$ polymorphisms, especially in patients with poor or impaired function of the enzyme CYP2D6.

\section{Disclosure}

The authors report no conflicts of interest in this work.

\section{References}

1. Jemal A, Bray F, Center MM, Ferlay j, Ward E, Forman D. Global cancer statistics. CA Cancer J Clin. 2011;61:69-90.

2. Stearns V, Rae JM. Pharmacogenetics and breast cancer endocrine therapy: CYP2D6 as a predictive factor for tamoxifen metabolism and drug response? Expert Rev Mol Med. 2008;e34. doi: 10.1017/ S1462399408000896

3. Brauch H, Mürdter T, Eichelbaum M, Schwab M. Pharmacogenomics of tamoxifen therapy. Clin Chem. 2009;55:1770-1782.

4. Briest S, Stearns V. Tamoxifen metabolism and its effect on endocrine treatment of breast cancer. Clin Adv Hematol Oncol. 2009;7(3): 185-192.

5. Ingel JN. Pharmacogenetics and pharmacogenomics of endocrine agents for breast cancer. Breast Cancer Res. 2008;10(Suppl 4):S4-S7.

6. Ingel JN. Pharmacogenomics of tamoxifen and aromatase inhibitors. Cancer. 2007;112(S3):695-699.

7. Hoskins JM, Carey LA, McLeod HL. CYP2D6 and tamoxifen: DNA matters in breast cancer. Nat Rev Cancer. 2009;9:576-586.

8. Beverage JN, Sissung TM, Sion AM, Danesi R, Figg WD. CYP2D6 polymorphisms and the impact on tamoxifen therapy. J Pharm Sci. 2007;96(9):2224-2231.

9. Higgins MJ, Stearns V. CYP2D6 Polymorphisms and tamoxifen metabolism: Clinical relevance. Curr Oncol Rep. 2010;12:7-15.

10. Goetz MP, Kamal A, Ames MM. Tamoxifen pharmacogenomis: the role of CYP2D6 as a predictor of drug response. Clin Pharmacol Ther. 2008;83(1):160-166.

11. Kurose K, Sugiyama E, Saito Y. Population differences in major functional polymorphisms of pharmacokinetics/pharmacodynamics-related genes in Eastern Asians and Europeans: Implications in the clinical trials for the novel drug development. Drug Metab Pharmacokinet. 2012;27(1):9-54.

12. Bernard S, Neville KA, Nguyen AT, Flockhart DA. Interethnic differences in genetic polymorphisms of CYP2D6 in the US population: clinical implications. Oncologist. 2006;11:126-135.

13. Ingelman-Sundberg M. Genetic polymorphisms of cytochrome P450 2D6 (CYP2D6): clinical consequences, evolutionary aspects and functional diversity. Pharmacogenomics J. 2005;5:6-13.

14. Benny K, Adithnan AC. Genetic polymorphisms of CYP2D6. Indian J Pharmacol. 2001;33:147-169.

15. Abraham JE, Maranian MJ, Driver KE, et al. CYP2D6 gene variants: association with breast cancer specific survival in a cohort of breast cancer patients for the United Kingdom treated with adjuvant tamoxifen. Breast Cancer Res. 2008;12(4):R64.

16. Schroth W, Goetz MP, Hamann U, et al. Association between CYP2D6 polymorphisms and outcomes among women with early stage breast cancer treated with tamoxifen. JAMA. 2009;302(13):1429-1436. 
17. Cajal TR, Altés A, Paré L, et al. Impact of CYP2D6 polymorphisms in tamoxifen adjuvant breast cancer treatment. Breast Cancer Res Treat. 2010;119(1):33-38

18. Borges S, Desta Z, Li L, et al. Quantitative effect of CYP2D6 genotype and inhibitors on tamoxifen metabolism: implication for optimization of breast cancer treatment. Clin Pharmacol Ther. 2006;80(1):61-74.

19. Blevins-Primeau AS, Sun D, Chen G, et al. Functional significance of UDP-glucuronosyltransferase variants in the metabolism of active tamoxifen metabolites. Cancer Res. 2009;69(5):1892-1900.

20. Guillemette C. Pharmacogenomics of human UDP-gluconosyltransferase enzymes. Pharmacogenomics J. 2003;3:136-158.

21. Lin GF, Guo WC, Chen JG. et al. An association of UDPglucuronosyltransferase 2B7 C802T (His268Tyr) polymorphism with bladder cancer in benzidine-exposed workers in China. Toxicol Sci. 2005;85(1):502-506.

22. Nakmahachalasint P. Genetic polymorphisms and CYP2D6 activity in Thai subjects [master's thesis]. Faculty of Pharmaceutical Sciences: Chulalongkorn University; 2003.

23. Pechatanan K, Jaruhathai S, Ativitavas T, et al. Cytochrome P4502D6 polymorphisms of Thai patients with breast cancer and their outcomes of adjuvant tamoxifen. J Clin Oncol. 2011;29(Suppl):e11037.

24. Sukasem C, Sirachainan E, Chamnanphon M, et al. Impact of CYP2D6 polymorphisms on tamoxifen Responses of woman with breast cancer: a microarray-based study in Thailand. Asian Pacific J Cancer Prev. 2012;13(9):4549-4553.

25. Zhu YB, Zhang Q, Zou JJ, et al. Optimizing high-performance liquid chromatography method with fluorescence detection for quantification of tamoxifen and two metabolites in human plasma: application to a clinical study. J Pharm Biomed Anal. 2008. 22;46(2):349-355.
26. Sirachainan E, Jaruhathai S, Trachu N, et al. CYP2D6 polymorphisms influence the efficacy of adjuvant tamoxifen in Thai breast cancer patients. Pharmacogenomics Pers Med. 2012;5:149-153.

27. Jin Y, Desta Z, Stearns V, et al. CYP2D6 genotype, antidepressant use, and tamoxifen metabolism during adjuvant breast cancer treatment. J Natl Cancer Inst. 2005;97(1):30-39.

28. Madlensky L, Natarajan L, Tchu S, et al. Tamoxifen metabolite concentrations, CYP2D6 genotype, and breast cancer outcomes. Clin Pharmacol Ther. 2011;89(5):718-725.

29. Kiyatoni K, Mushiroda T, Imamura CK, et al. Dose-adjustment study of tamoxifen based on CYP2D6 genotypes in Japanese breast cancer patients. Breast Cancer Res Treat. 2011;131:137-145.

30. Ahern TP, Christensen M, Cronin-Fenton DP, et al. Functional polymorphisms in UDP-glucuronosyl transferases and recurrence in tamoxifentreated breast cancer survivors. Cancer Epidemiol Biomarkers Prev. 2011;20(9):1937-1943.

31. Rae JM, Drury S, Hayes DF, et al. CYP2D6 and UGT2B7 genotype and risk of recurrence in tamoxifen-treated breast cancer patients. J Natl Cancer Inst. 2012;21;104(6):452-460.

32. Mürdter TE, Schroth W, Bacchus-Gerybadze, et al. Activity levels of tamoxifen metabolites at the estrogen receptor and the impact of genetic polymorphisms of phase I and II enzymes on their concentration levels in plasma. Clin Pharmocol Ther. 2011;89(5):708-717.

\section{Publish your work in this journal}

Breast Cancer: Targets and Therapy is an international, peerreviewed open access journal focusing on breast cancer research, identification of therapeutic targets and the optimal use of preventative and integrated treatment interventions to achieve improved outcomes, enhanced survival and quality of life for the cancer patient.

\section{Dovepress}

View the full aims and scopes of this journal here. The manuscript management system is completely online and includes a very quick and fair peer-review system, which is all easy to use. Visit http:// www.dovepress.com/testimonials.php to read real quotes from published authors. 